\title{
The Rates of Changining Confined Aquifer Hydraulic Parmeters under Dynamic Conditions, Area Three in Darb El Arbeain, South Western Desert, Egypt
}

\author{
Gamal H. El Saeed, Neveen B. Abdelmageed, Peter Riad, M. Komy
}

\begin{abstract}
Darb El-Arbeain area lies between long. 29o 00/ and $31000 / E$ and lat. $22000 /$ and 240 30/ N. In this study the changing rates of the hydraulic parameters are investigated through different pumping rates using the three dimensional finite difference flow model (MODFLOW 2005) to simulate the flow system. The initial aquifer hydraulic parameters are; The average hydraulic gradient is 0.00259 , the initial transmissivity value is $1075 \mathrm{~m} 2 /$ day, average hydraulic conductivity is $6.5 \mathrm{M} /$ day, and average flow rate in the aquifer $=0.01683 \mathrm{~m} /$ day. Under different pumping rates a general trend is introduced to the rates of changing different hydraulic parameters, and the governing equations.
\end{abstract}

Keywords :: Darb El-Arbeain, hydraulic parameters, hydraulic conductivity.

\section{INTRODUCTION}

The groundwater is the sole resource of water in arid area for farmers from Paris town towards the Egypt-Sudan border. The Nubian sandstone aquifer in the area of study is capped by a confining bed (Dakhla Formation) and underlain by basement rocks (Issawi 1971; Karimova et al., 2018). Managing and improving the performance of the confined aquifer is mainly based on better understanding of the rate and trend of changing the hydraulic parameters of the confined aquifer under different pumping rates.

\section{MODEL DESCRIPTION AND CALIBRATION FOR NORTHERN AREA OF DARB EL ARBEAIN}

2-1 The Governing Partial Differential Equation for a confined aquifer used in MODFLOW is (WHI, 2002):

$$
\frac{\partial}{\partial x}\left[K_{x x} \frac{\partial h}{\partial x}\right]+\frac{\partial}{\partial y}\left[K_{y y} \frac{\partial h}{\partial y}\right]+\frac{\partial}{\partial z}\left[K_{z z} \frac{\partial h}{\partial z}\right]+W=S_{S} \frac{\partial h}{\partial t}
$$

Revised Manuscript Received on September 25, 2019

* Correspondence Author

Gamal H. El Saeed; Faculty of Engineering, Shoubra, Banha University, Egypt

Neveen B. Abdelmageed; Faculty of Engineering, Shoubra, Banha University, Egypt

Peter Riad' Grassland Science and Renewable Plant Resources, University of Kassel, Germany

Irrigation and Hydraulics Dept. Faculty of Engineering, Ain Shams University

M. Komy' Faculty of Engineering, Shoubra, Banha University, Egypt
2-2 For The Steady Flow In Porous Anistropic Saturated Medium subsitution of Darcy law for $\mathrm{v}$ in $\mathrm{x}, \mathrm{y}$ and $\mathrm{z}$ direction yields to;

$$
\begin{aligned}
& \mathrm{x}(\mathrm{Kx} \partial \mathrm{h} / \partial \mathrm{x})+\partial / \partial \mathrm{y}(\mathrm{Ky} \partial \mathrm{h} / \partial \mathrm{y})+\partial / \partial \mathrm{z}(\mathrm{Kz} \partial \mathrm{h} / \partial \mathrm{z}) \\
& =0 \quad \partial / \partial
\end{aligned}
$$

for the isotropic medium ; $\mathrm{Kx}=\mathrm{Ky}=\mathrm{K} \mathrm{z}$ and for homogenious medium $\mathrm{K}(\mathrm{x}, \mathrm{y}, \mathrm{z})=$ constant.

2-3 Trsnsit Flow Conservation Law In Asaturated Porous Medium

The net rate of fluid mass into any element control volume $=$ the changes time rate in the stored fluid mass within the element, and continuity equation will be;

$(-\partial(\rho v \mathrm{x}) / \partial \mathrm{x})-(\partial(\rho \mathrm{vy}) / \partial \mathrm{y})-(\partial(\rho \mathrm{z}) / \partial \mathrm{z})=\mathrm{n}(\partial$ $\rho / \partial \mathrm{t})+\rho(\partial \mathrm{n} / \partial \mathrm{t})$

Where;

n $(\partial \rho / \partial t)$; the effect of density

( $\rho$ ) chages on the expansion of the produced water mass rate, controlled by fluid compressibility $\beta$. And

$\rho(\partial \mathrm{n} / \partial \mathrm{t})$; the effect of the porous medium compaction due to changes of porosity $n$, controlled by the aquifer compressibility $\alpha$.

2-4 Initial Model Input (First Assumption);

The hydraulic conductivity;

$\mathrm{Kx}=\mathrm{Ky}=6.5 \mathrm{~m} /$ day

$\mathrm{Kz}=0.65 \mathrm{~m} /$ day, no of aquifers; 1 ,

no of rows $=200$,

no of columns $=200$ (each cell is $50 * 50 \mathrm{mt}$ ),

Average Specific storativity $=.0001 \mathrm{~m}-1$,

Average total porosity $=0.3$,

average effective porosity $=0.15$ (El-Beih, 2007), Piezometric level; taken from Korany et al. 2002, (Fig. 2). Boundary conditions (Fig. 3); the western boundary; consist 3 segments, line a-b represent constant head $205 \mathrm{mt}$, mean while line from b-c represents $204 \mathrm{mt}$, and line c-d represents $218 \mathrm{~m}$. The eastern boundary; line e-f represent constant head $219 \mathrm{mt}$, and line f-g represent Constant head $226 \mathrm{mt}$, and line g-h represent constant head $222 \mathrm{~m}$. the southern

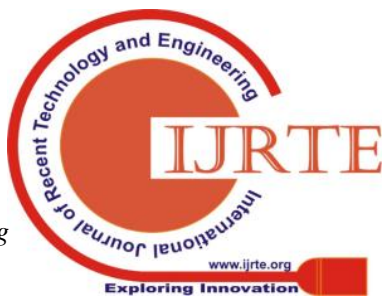


The Rates of Changining Confined Aquifer Hydraulic Parmeters under Dynamic Conditions, Area Three in Darb El Arbeain, South Western Desert, Egypt

parts line d-e represent constant head $223 \mathrm{mt}$. the northern parts represent no flow boundary. Calibration, $92 \%$, (Fig. 4) involved comparison of the model results and observed heads at observation points from a piezometric head map to run in a steady state simulation, once the model calibrated, the calculated hydraulic heads were used as initial heads for the transient flow scenarios.

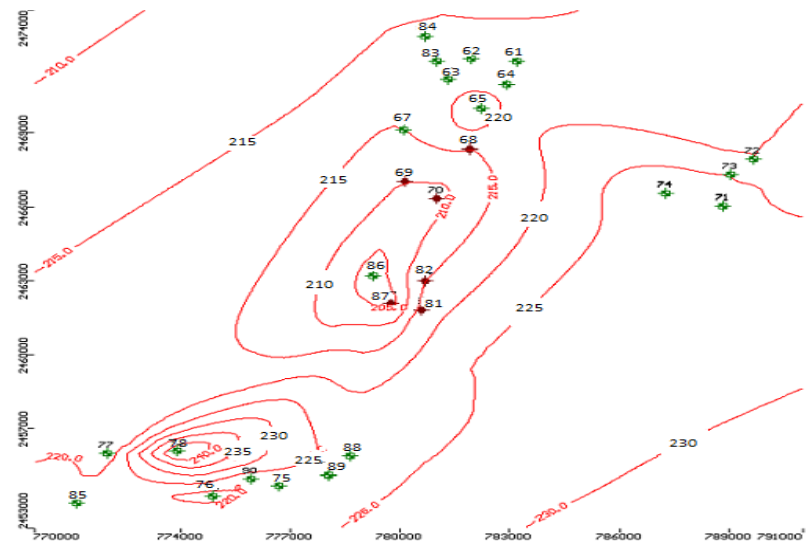

Figure 2: piezometric levels, $\mathrm{m}$, in araea three, Darb El Arbeain

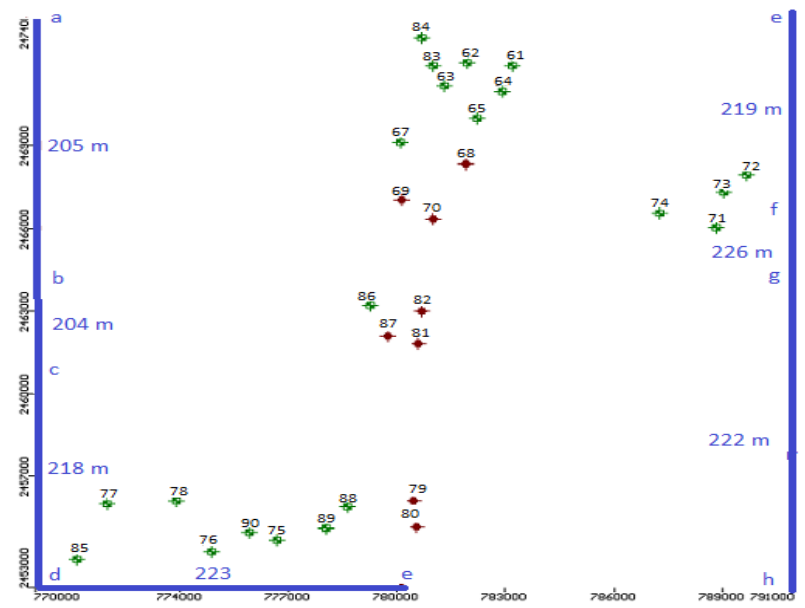

Figure 3: boundary condition heads, $\mathrm{m}$, in area three of Darb El Arbeain

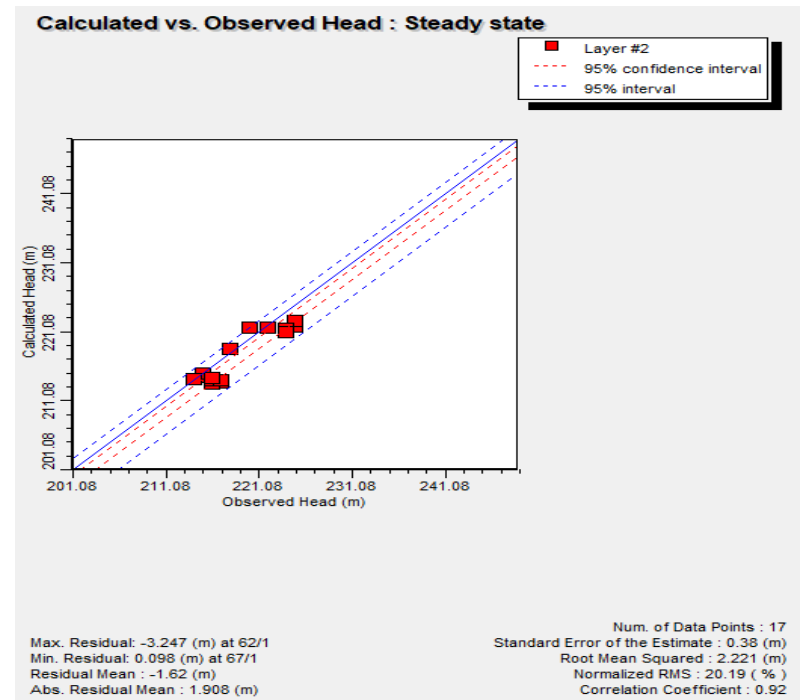

Figure 4:calibration results in area three of Darb El Arbeain

\section{AQUIFER RESPOND FOR THE DIFFERENT PUMPING SCENARIOS}

3-1 Pumping out=1.1 of initial recharge (each well 1800 $\mathrm{m}^{3} / \mathrm{d}$ ), Fig. (5)

3-1-1 Drawdown and Time for Water Level Equilibrium

From the modelling; The maximum average expected (interpolated) drawdown is $14 \mathrm{mt}$ and expected time for stability or equilibrium is around 25 years.

3-1-2 The New Specification of the Aquifer When Reach Equilibrium

1- Average New Hydraulic Gradient in The Area

$=$ average initial hydraulic gradient + average initiated due to pumping

$=$ initial hydraulic gradient + (average max. drawdown / total length of the area)

$$
=0.00259+(14 / 21000)=0.00325
$$

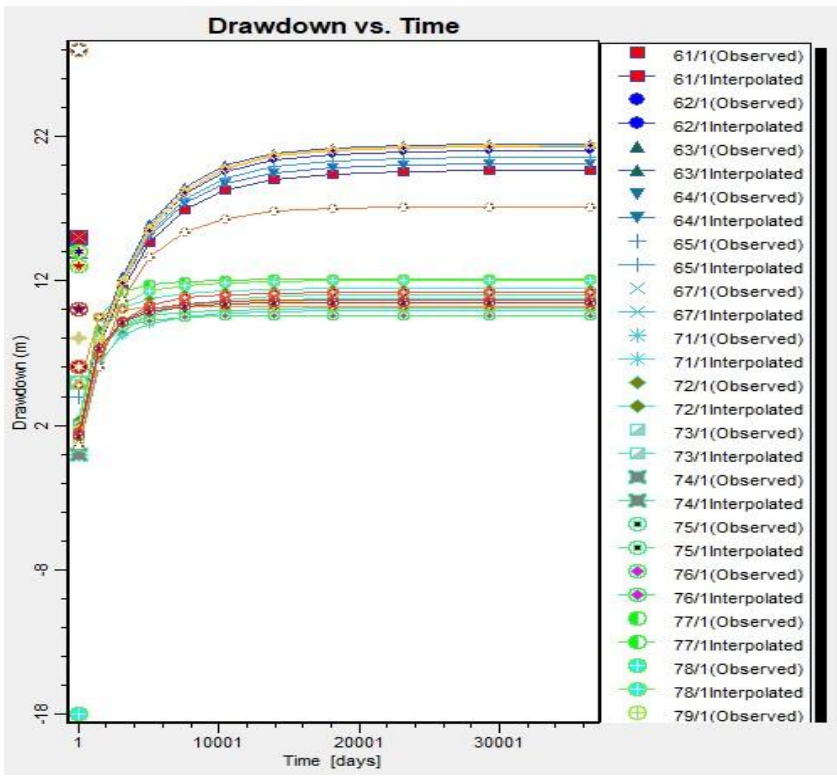

Figure 5: The modelling results; Drawdown Vs time at Q ${ }_{\text {out }} / Q_{\text {in }}=110 \%$, area three

2- Calculate New Average Transmissivity Value

$\mathrm{Q}=$ TIW (Darcy's Law); T: Transmissivity ( $\mathrm{T}=\mathrm{KD}$, where, K: hydraulic conductivity, and

D: Total thickness). W: Width of area, I: Hydraulic gradient.

New average transmissivity $=(\mathrm{Q} / \mathrm{I} * \mathrm{~W})=54000 /$ $(0.00325 * 21000)=791 \mathrm{~m}^{2} /$ day

(old value $1075 \mathrm{~m}^{2} /$ day, Kamel,2004)

3- to calculate new average hydraulic conductivity value;

$\mathrm{K}=\mathrm{T} / \mathrm{D}=791 / 168=4.7 \mathrm{M} /$ day (old average value $6.5 \mathrm{M} /$ day, Kamel ,2004)

4. To calculate new average flow rate in the discharge area; 
$\mathrm{V}=\mathrm{K} * \mathrm{I}=4.7 * 0.00325=0.01530 \mathrm{~m} /$ day (old average value $=0.01683 \mathrm{~m} /$ day)

4-1 Pumping out=1.8 of recharge (each well $\left.3000 \mathrm{~m}^{3} / \mathrm{d}\right)$ 4-2-1 drawdown and time for water level equilibrium

The average maximum expected drawdown is around 18 $\mathrm{mt}$, and the years required for equilibrium is around 30 years.

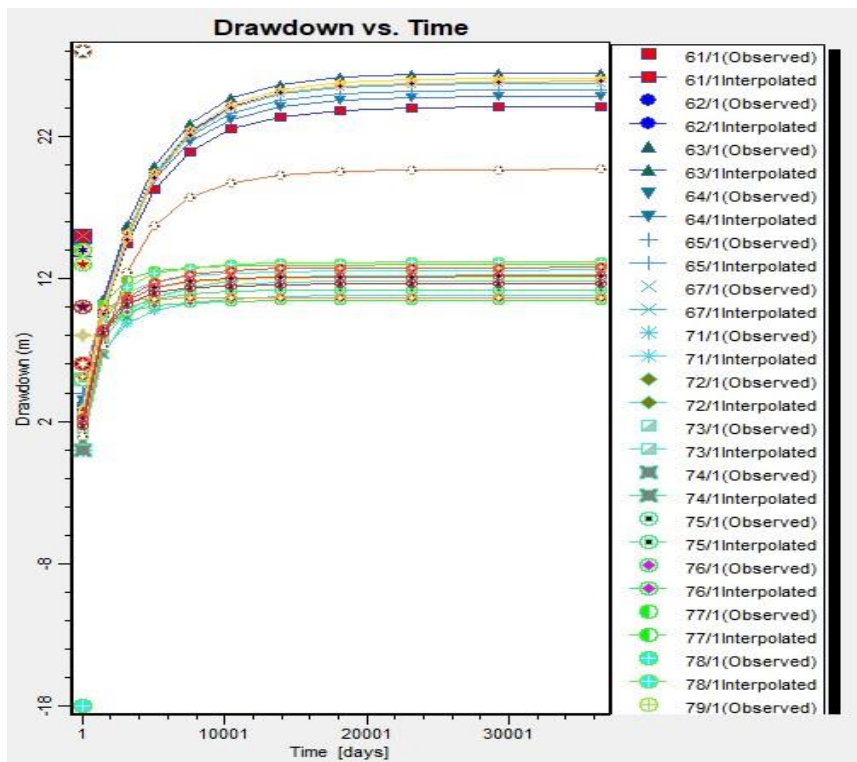

Figure 6: The modelling results; Drawdown Vs time at Q ${ }_{\text {out }} / Q_{\text {in }}=180 \%$, area three

3-2-2 The New Specification of the Aquifer When Reach Equilibrium

1- Average New Hydraulic Gradient in The Area; $=$ average initial hydraulic gradient + average initiated due to pumping $=$ initial hydraulic gradient + (average max.

drawdown / total length of the area)

$$
=0.00259+(18 / 21000)=0.00344
$$

2- Calculate New Average Transmissivity Value

$\mathrm{Q}=$ TIW (Darcy's Law); T: Transmissivity $(\mathrm{T}=\mathrm{KD}$, where, $\mathrm{K}$ : hydraulic conductivity, and

D: Total thickness). W: Width of area, I: Hydraulic gradient. New average transmissivity $=(\mathrm{Q} / \mathrm{I} * \mathrm{~W})=90000 /$ $(0.00344 * 21000)=1245 \mathrm{~m}^{2} /$ day.

(old value $1075 \mathrm{~m}^{2} /$ day, Kamel,2004)

3- Calculate New Average Hydraulic Conductivity Value

$\mathrm{K}=\mathrm{T} / \mathrm{D}=1245 / 168=7.41 \mathrm{M} /$ day (old average value $6.5 \mathrm{M} /$ day, Kamel ,2004)

4. Calculate New Average Flow Rate In The Discharge Area

$\mathrm{V}=\mathrm{K} * \mathrm{I}=7.41 * 0.00344=0.02549 \mathrm{~m} /$ day (old average value $=0.01683 \mathrm{~m} /$ day)

3-3 Pumping Out=2.8 Of Recharge (Each Well $\left.4600 \mathrm{~m}^{3} / \mathrm{d}\right)$, Fig. (7)

4-2-2 drawdown and time for water level equilibrium

4-2-3

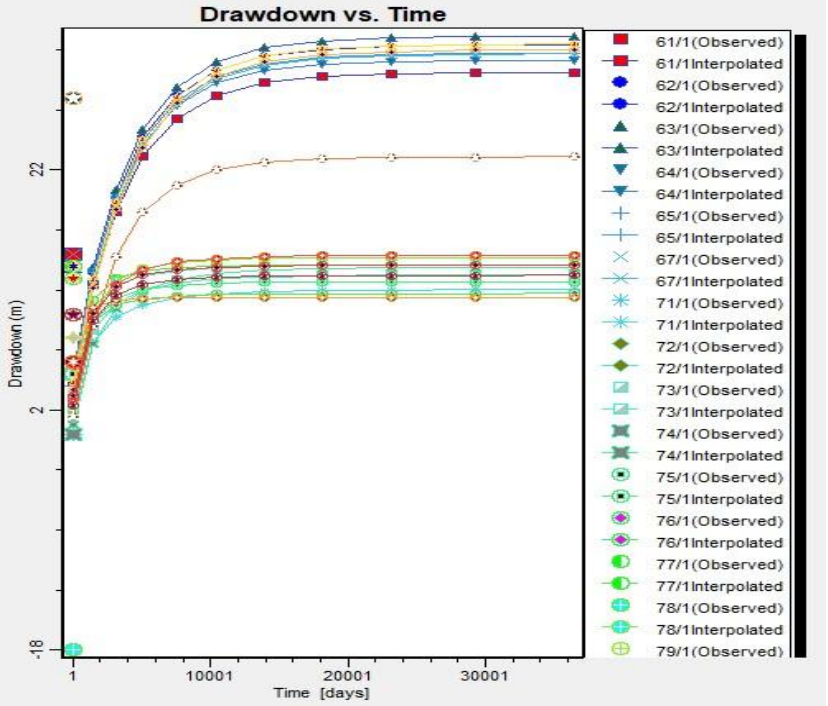

Figure 7: The modelling results; Drawdown Vs time at Q ${ }_{\text {out }} / Q_{\text {in }}=280 \%$, area three

The average drawdown is $23 \mathrm{mt}$, and the average maximum time for equilibrium is 40 years.

3-3-2 The New Specification of the Aquifer When Reach Equilibrium

1- Average New Hydraulic Gradient in The Area; $=$ average initial hydraulic gradient + average initiated due to pumping $=$ initial hydraulic gradient + (average max. drawdown / total length of the area)

$$
=0.00259+(23 / 21000)=0.00368
$$

2- To Calculate New Average Transmissivity Value;

$\mathrm{Q}=$ TIW (Darcy's Law); T: Transmissivity ( $\mathrm{T}=\mathrm{KD}$, where, K: hydraulic conductivity, and

D: Total thickness). W: Width of area, I: Hydraulic gradient.

New average transmissivity $=(\mathrm{Q} / \mathrm{I} * \mathrm{~W})=138000 /(0.00368$ $* 21000)=1785 \mathrm{~m}^{2} /$ day.

(old value $1075 \mathrm{~m}^{2} /$ day, Kamel,2004)

3- To Calculate New Average Hydraulic Conductivity Value; $\mathrm{K}=\mathrm{T} / \mathrm{D}=1785 / 168=10.62 \mathrm{M} /$ day (old average value $6.5 \mathrm{M} /$ day, Kamel ,2004)

4. To Calculate New Average Flow Rate in The Discharge Area;

$\mathrm{V}=\mathrm{K} * \mathrm{I}=10.62 * 0.00368=0.03911 \mathrm{~m} /$ day (old average value $=0.01683 \mathrm{~m} /$ day)

4-3 All Wells Pumping Out $=3.7$ Of Initial Recharge (Run All Wells $6000 \mathrm{~m}^{3} /$ day), Fig. (8)

4-4-1 Drawdown and Time for Water Level Equilibrium

The maximum average drawdown is $28 \mathrm{mt}$, and the average time for equilibrium is 45 years.

4-4-2 The New Specification of the Aquifer When Reach Equilibrium

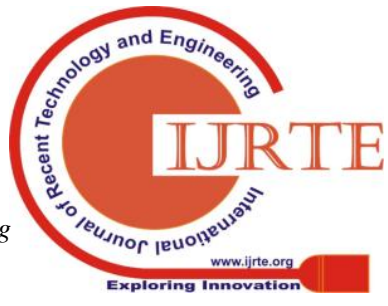


The Rates of Changining Confined Aquifer Hydraulic Parmeters under Dynamic Conditions, Area Three in Darb El Arbeain, South Western Desert, Egypt

a- average new hydraulic gradient in the area;

$=$ average initial hydraulic gradient + average initiated due to pumping

= initial hydraulic gradient + (average max. drawdown / total length of the area)

$$
=0.00259+(28 / 21000)=0.003923
$$

b- To Calculate New Average Transmissivity Value

$\mathrm{Q}=$ TIW (Darcy's Law); T: Transmissivity (T=KD,

where, K: hydraulic conductivity, and

D: Total thickness). W: Width of area, I: Hydraulic gradient.

New average transmissivity $=(\mathrm{Q} / \mathrm{I} * \mathrm{~W})=180000 /$

$(0.003923 * 21000)=2185 \mathrm{~m}^{2} /$ day .

(old value $1075 \mathrm{~m}^{2} /$ day, Kamel,2004)

c- To Calculate New Average Hydraulic Conductivity Value

$\mathrm{K}=\mathrm{T} / \mathrm{D}=2185 / 168=13 \mathrm{M} /$ day (old average value $6.5 \mathrm{M} /$ day, Kamel ,2004)

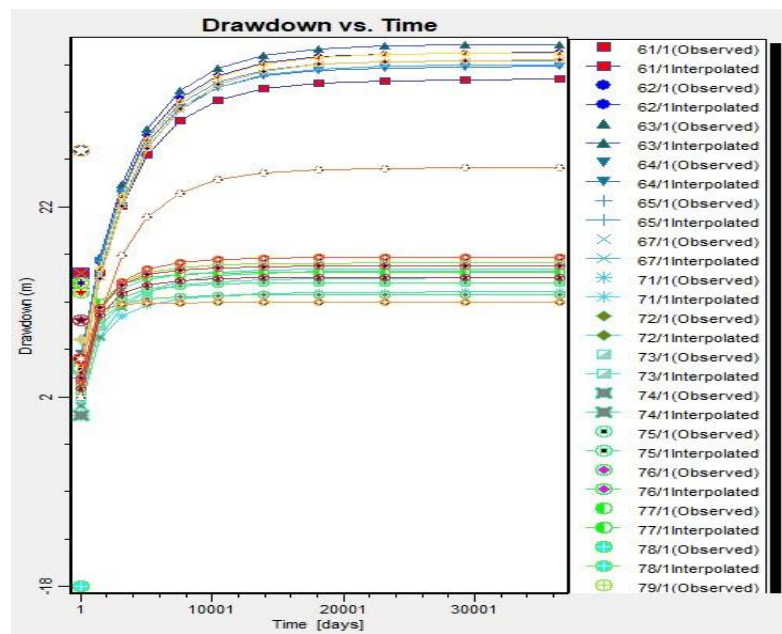

Fig. (8): The modelling results; Drawdown Vs time at Q ${ }_{\text {out }} / Q_{\text {in }}=370 \%$, area three

d. To Calculate New Average Flow Rate in The Discharge Area

$\mathrm{V}=\mathrm{K} * \mathrm{I}=13 * 0.003923=0.05086 \mathrm{~m} /$ day (old average value $=0.01683 \mathrm{~m} /$ day)

4-4 Summary of Confined Aquifer Drawdown and Hydraulic Parameters Changing Rates

4-5-1 Changing Rate of Confined Aquifer Parameters

The changing rate of the confined aquifer hydraulic parameters is best illustrated in table 3 .

Table 1. new aquifer specifications as percentage of initial specifications

\begin{tabular}{|c|c|c|c|c|}
\hline $\begin{array}{c}\mathrm{Q}_{\text {out }} / \mathrm{Q} \\
\text { in(initial) }\end{array}$ & $\begin{array}{c}\text { I after equilibrium } \\
\text { ratio to initial value }\end{array}$ & $\begin{array}{c}\mathrm{T} \text { after } \\
\text { equilibrium ratio to } \\
\text { initial value }\end{array}$ & $\begin{array}{c}\text { K after equilibrium } \\
\text { ratio to initial value }\end{array}$ & $\begin{array}{c}\text { Flow rate after } \\
\text { equilibrium ratio to } \\
\text { initial value }\end{array}$ \\
\hline 1.1 & 1.25 & 0.73 & 0.72 & 1.07 \\
\hline 1.8 & 1.32 & 1.15 & 1.14 & 2.32 \\
\hline 2.8 & 1.42 & 1.66 & 1.63 & 3.02 \\
\hline 3.7 & 1.51 & 2.03 & 2 & \\
\hline
\end{tabular}

a- The Hydraulic Gradient (I) Rate of Change

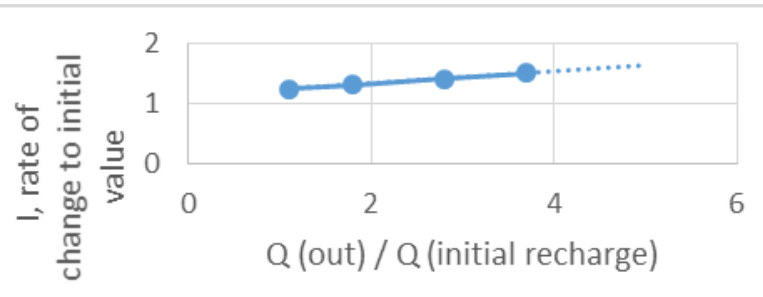

Figure 9: Hydraulic gradient changing rate under dynamic conditions

The hydraulic gradient changing rate is illustrated in Fig. (9), and the following equation is controlling the new value for the hydraulic gradient,

$$
I_{\text {new }}=\text { constant } * I_{\text {initial }} *\left(Q_{\text {out }} / \mathbf{Q}_{\text {in }}\right)
$$

Where the constant is averagely taken as 0.68 , and that constant was taken averagely due to the homogeneity degree of the aquifer formation. b- Transmissivity Change Rate, $\mathrm{T}$

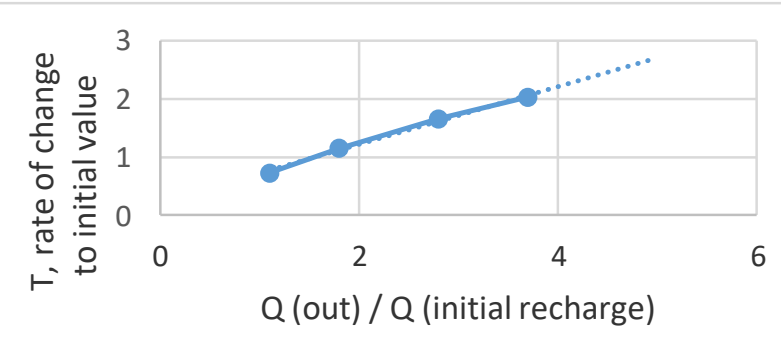

Figure 10: Transmissivity changing rate in the dynamic conditions

The transmissivity rate of change is illustrated in Fig (10), and the following equation is controlling the new value for the transmissivity,

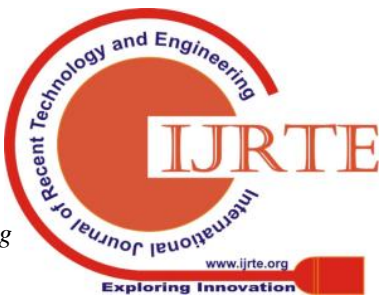




$$
\mathbf{T}_{\text {new }}=\text { constant } * \mathbf{T}_{\text {initial }} *\left(\mathbf{Q}_{\text {out }} / \mathbf{Q}_{\text {in }}\right)
$$

Where the constant is averagely taken as 0.60 , and that constant was taken averagely due to the homogeneity degree of the aquifer formation.

c-The Hydraulic Conductivity, K, rate of change

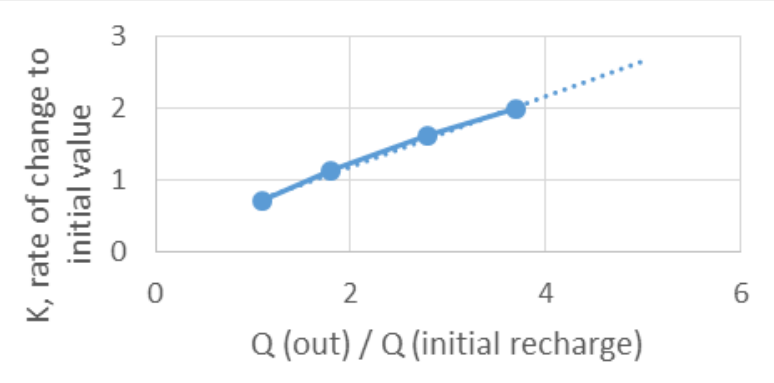

Figure 11: Hydraulic conductivity changing rate in the dynamic conditions

The hydraulic conductivity rate of change is illustrated in Fig. (11), and the following equation is controlling the new value for the hydraulic conductivity,

$$
\mathbf{K}_{\text {new }}=\text { constant } * \mathbf{K}_{\text {initial }} *\left(\mathbf{Q}_{\text {out }} / \mathbf{Q}_{\text {in }}\right)
$$

Where the constant is averagely taken as 0.60 , and that constant was taken averagely due to the homogeneity degree of the aquifer formation.

Table (2) confined aquifer Drawdown response, southern part of Darb El Arbeain

\begin{tabular}{|c|c|c|}
\hline $\mathrm{Q}_{\text {out }} / \mathrm{Q}_{\text {in(initial) }}$ & Average drawdown, $\mathrm{m}$ & Time for equilibrium, years \\
\hline 1.1 & 14 & 25 \\
\hline 1.8 & 18 & 30 \\
\hline 2.8 & 23 & 40 \\
\hline 3.7 & 28 & 45 \\
\hline
\end{tabular}

d- Flow Rate Changing Rate

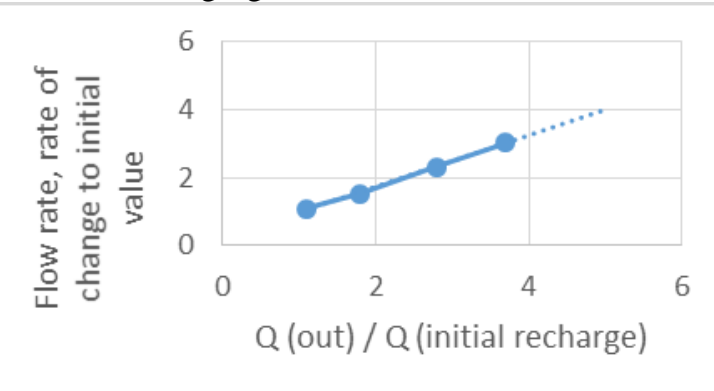

Figure 12: Flowrate changing rate in the dynamic conditions

The flow rate changing rate is illustrated in Fig (12), and the following equation is controlling the new value for the flow rate,

Flow rate new $=$ constant $^{*}$ flow rate initial $^{*}\left(\mathbf{Q}_{\text {out }} / \mathbf{Q}_{\text {in }}\right)$

Where the constant is averagely taken as 0.86 , and that constant was taken averagely due to the homogeneity degree of the aquifer formation and the effective porosity.

\section{4-5-2 Changing Rate of Aquifer Drawdown} the drawdown changing rate is illustrated in below Fig. (13), and table (2) a- Time for Drawdown Stability;

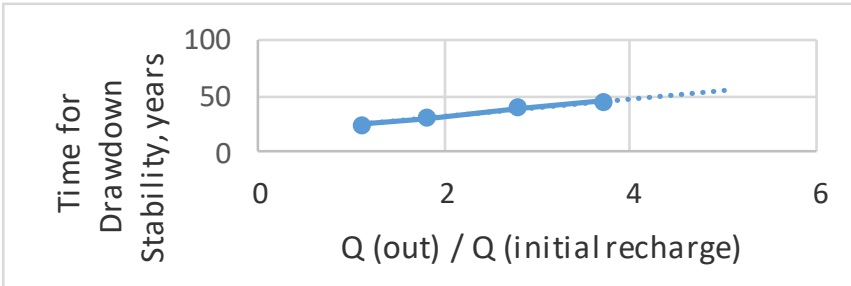

Figure 14: Time for Drawdown Equilibrium under dynamic condition in southern area

Time for drawdown stability, years $=$ constant $*\left(\mathbf{Q}_{\text {out }}\right)$

$\mathbf{Q}$ initial recharge)

The constant is averagely equal to 16 , and depends on the aquifer homogenous degree, aquifer specification, and exploitation rates.

\section{CONCLUSION}

The study area occupies the southern part of Darb El Arbeain. It is characterized by arid climatic conditions. Different pumping scenarios were applied through applying visual modflow and correlation with field data. The results indicated that the new value of hydraulic gradient, hydraulic conductivity, flow rate and the transmissivity could be controlled through; Hydraulic parameter new = constant $*$ Hydraulic parameter initial * (Q out/ $Q$ in $)$, the constant averagely is 0.60 for all, except for flow rate the constant is averagely 0.86 and the constant is controlled by the homogeneity degree of the aquifer. Time for drawdown stability in years $=$ constant $*(\mathrm{Q}$ out $/ \mathrm{Q}$ initial recharge $)$, and the constant is 16 depending on the exploitation rate, aquifer recharge, and the aquifer homogeneity degree.

\section{RECOMMENDATIONS}

For any management plan to be successful for southern part of Darb El Arbeain, the aquifer parameters must be addressed. This is due to the fact that it has high impacts on water management and land reclamation in a ride area, drawdown and heads.

\section{REFERENCES}

1. Ahmed Hassan, Gamal Elsaeed, Mohamed Nagaty, Eman Abdelghani. (2015). Groundwater Flow Modelling in A Nubian Sandstone Aquifer, South Western Desert, Egypt.
Blue Eyes Intelligence Engineering \& Sciences Publication 
2. Abdel-Lattif. A.and Mohamed El Kashouty. (2009). Statical investigation of the groundwater system in Darb El Arbeain, south western desert, Egypt.

3. A.M. S Gejam P. H.S. Riad, M.A. Gad, K.A. Rashed and N.A. Hasan. (2016). impact of Pumping Rate on Seawater Intrusion in Jefara Plain, Libya.

4. Ambroggi, R. (1966). Water under the Sahara: Scientific American, v 214, no 5 .

5. Rocha, T., Martins, J., Branco, F., and Gonçalves, R. (2017). Evaluating Youtube Platform Usability by People with Intellectual Disabilities (A User Experience Case Study Performed in a Six-Month Period). Journal of Information Systems Engineering \& Management, 2(1), 5. https://doi.org/10.20897/jisem.201705

6. Continental Oil Company (CONOCO, 1989). Geologic map of Egypt, scale $1 ; 50000$.

7. Development and Application of a Groundwater/ Surface-Water Flow Model using MODFLOW-NWT for the Upper Fox River Basin, South eastern Wisconsin. (2012).

8. Karimova, B., Ongarbayeva, A., Sebepova, R., Aubakirova, A., \& Mirzabekova, M. (2018). Synergetic approach in trilingua education of the Republic of Kazakhstan. Opción, 34(85), 327-343.

9. El Gammal, N. 2004. Hydrogeological studies in Darb ElArbaein area, south Egypt. Master science, Geology Department, Cairo university.

10. El Kashouty, M. A. \& Abdel-Lattif A. (2010) Groundwater management in the Darb El Arbaein, South western desert, Egypt. International Journal of Water Resources and Environmental Engineering Vol.1 (5).

11. Mardani, M., Lavasani, S. M., \& Omidvari, M. (2014). An investigation into DOW and MOND indices with fuzzy logic based on fire and explosion risk assessment in Iran oil refinery, UCT Journal of Research in Science, Engineering and Technology, 2(3): 126-137.

12. El Sabri, M. \& Shedid A. (2014) Impact of Wells's Design on Their Productivity in Selected Areas in the Western Desert, Egypt. Egy. J. Pure \& Appl. Sci. (2014); 52(1):37-46.

13. Fathy, R., El Nagaty, M., Atef, A. and El Gammal, N. (2002).Contribution of the hydrogeological and hydrochemical charateteristics of Nubian sandstone aquifer in Darb ElArbaein, south western Desert, Egypt. Al Azhar Bull Sciv13 no2; 69-100.

14. General Survey of Egypt (EGMSA), (1987). Geophysical investigation of the Egyptians transitional sandstone project; Report to groundwater research Institute, Egypt.

15. German Water Group, (1977), Hydrogeological study of groundwater resources in the Kufra area: German Water Engineering, GB, Vol. 5.

16. Journal of American Science (2013); 9 (6).

17. Twentieth International Water Technology Conference, IWTC20 Hurghada, 18-20 May (2017)

18. Issawi, B., (1971), Geology of Darb EL- Arbian, Western Desert, Egypt: Ann. G.S.E., Cairo.

19. International Journal of Geosciences Vol.3 No.5(2012), Article ID:24988,13 pages.

20. Sustainable Groundwater Management Policy Directives June (2016), Mexico City, Mexico. 